\title{
Accounting Harmonisation through IAS/IFRS and Internationalisation: Evidence from FDIs and Cross-Border M\&A
}

\author{
Damiano Montani ${ }^{1}$, Daniele Gervasio ${ }^{1}$, Andrea Pulcini ${ }^{1}$ \& Camilla Marchesi ${ }^{1}$ \\ ${ }^{1}$ Department of management, University of Bergamo, Bergamo, Italy \\ Correspondence: Damiano Montani, University of Bergamo, Bergamo, Italy.
}

Received: June 30, 2021

Accepted: July 22, 2021

Online Published: July 23, 2021

doi:10.5430/afr.v10n3p44

URL: https://doi.org/10.5430/afr.v10n3p44

\begin{abstract}
The process of accounting harmonisation via International Accounting Standards/International Financial Reporting Standards (IAS/IFRS) adoption is very widespread, and it is still involving a huge number of countries all over the world.

Previous academic literature investigated the impact of this process from different perspectives, such as the quality of financial reports, the transparency of financial disclosures, the liquidity of the financial markets and the cost of equity.

The aim of this article is to contribute to the research stream exploring the effects of IAS/IFRS adoption, investigating if accounting harmonisation through the IAS/IFRS has had an impact on the internationalisation process.

To achieve our objective, two multiple linear regression analyses are presented. The first one focuses on the impact of the adoption of IAS/IFRS on foreign direct investments (FDIs) using data collected from a sample of 34 Organisation for Economic Co-Operation and Development (OECD) member countries. The second statistical analysis investigates the influence of IAS/IFRS adoption on cross-border mergers and acquisitions (M\&A), considering operations carried out by European-listed companies towards target companies located in the 34 OECD member countries. The FDIs and cross-border M\&A are considered proxies of the internationalisation process.

Preliminary results show that the adoption of IAS/IFRS has positively affected FDI flows and increased the value of cross-border M\&A.

This study has tried to provide theoretical contributions to the literature stream about the effects of the harmonisation process with IAS/IFRS adoption, showing the beneficial impact they may have on the internationalisation process. Moreover, our findings can be useful for policymakers and managers, suggesting that becoming IAS/IFRS adopters can facilitate the internationalisation process of the companies.
\end{abstract}

Keywords: accounting harmonisation, FDI, IAS/IFRS, internationalisation, M\&A

\section{Introduction}

The difference in accounting rules is a very big problem for international investors because they have to bear more costs to correctly understand the financial reports of companies operating in different countries (Nobes et al., 2008).

In academic literature, various studies were made to explain why accounting systems are different among countries (Choi \& Meek, 2008; Radebaught et al., 2006). Some scholars outline the role played by the culture of each country (Grey, 1988); others considered the legal culture, distinguishing among common low and civic law countries (Jaggi \& Low, 2000; Bushman \& Piotrosky, 2006). Still others focus on the casual factors (Soeters \& Schreuder, 1988).

The development of international commerce, financial markets and the globalisation process (including its political and social dimensions) brought an increasing need of overcoming (or at least to reduce) deformities in accounting regulation (Chua \& Taylor, 2008).

In order to try to solve this trouble, the International Accounting Standard Board (IASB) has issued the International Accounting Standards/International Financial Reporting Standards (IAS/IFRS). They are a set of high-quality accounting principles thought to be adopted all over the world, granting transparency by enhancing the international comparability, accountability by reducing the information gap between the providers of capital and the investors, and 
efficiency by helping investors to identify opportunities and risks across the world (IFRS Foundation, 2021a). Approximately 120 nations and reporting jurisdictions permit or require IFRS for domestic-listed companies, and approximately 90 countries have fully conformed to the IFRS as promulgated by the IASB (IFRS Foundation, 2021b). The European Union (EU) decided to bet on the adoption of the IAS/IFRS, particularly for the consolidated financial report of listed companies, leaving autonomy to each country member to extend the adoption of IAS/IFRS to other companies and also to individual financial reports (European Regulation n. 1606/2002).

The most important economies in the world adopted/started a convergence process with the IAS/IFRS (Ramanna \& Sletten, 2014). This is because countries expected to have many advantages from a common accounting language for instance, a reduction of transaction costs and better availability of information.

Academic literature has brought attention to investigating the effects of accounting harmonisation through the spread of IAS/IFRS. Some scholars outlined an increase in comparability and transparency of information (Barth et al., 2012; Cascino \& Gassen, 2015; Kainth \& Wahlstrøm, 2021), while others show how the adoption of the IAS/IFRS improved the liquidity in the financial market (Coyring et al., 2007; Istiningrum, 2020). Still others underline beneficial such as the reduction of the cost of debt (Ozkaya, 2018) and the cost of equity (Li, 2010; de Moura et al., 2020).

This article wishes to contribute to the research stream about the effects arising from the adoption of international accounting standards, by exploring if a process of accounting harmonisation with the IAS/IFRS can impact the internationalisation process.

To achieve this aim, we developed two multilinear regression analyses. The first one focused on the impact of IAS/IFRS adoption on foreign direct investments (FDIs). Data were collected by 34 Organisation for Economic Co-Operation and Development (OECD) member countries, considering a time horizon from 2003 to 2012. The second statistical analysis put attention to the relation among IAS/IFRS adoption and cross-border mergers and acquisitions (M\&A). The data considers operations carried out from 2005 to 2015 by European-listed companies towards target companies located in the 34 OECD member countries. Notably, FDIs and cross-border M\&A are considered proxies of the internationalisation process.

Our preliminary results show that the adoption of IAS/IFRS positively affects FDI flows and the value of cross-border M\&A. So, we argue in this paper that the adoption of a common accounting language can support the internationalisation process of the companies. These findings can give a theoretical contribution to accounting literature about the effects of the adoption of IAS/IFRS, and they can be useful to policymakers, accounting standard regulators and managers in making decisions about the adoption of IAS/IFRS.

The rest of the paper begins with the second section where we present a short literature review in order to develop our hypotheses. In the third section, we describe the method adopted and give all information about samples and variables; with the fourth section, we show the results. This is followed by an interpretation of the results and then the paper concludes with a discussion.

\section{Literature Review and Hypothesis Development}

One of the main problems that discourages investors from taking business opportunities in foreign countries is information asymmetry (Brennan \& Cao, 1997; Jiang \& Kim, 2004; Chung et al., 2017; Vo, 2020). As stated by Dikova et al. (2010, p. 227), 'the pressure for compliance with host-country rules and laws that a foreign acquirer cannot easily comprehend may obstruct the deal completion; or it may require a substantial amount of time to finalise'. Broadly speaking, familiarity - defined as the increase in investor understanding of the business environment, leaving the quality of information constant (Amiram, 2012) - is a very important element to make the investors feel more competent about the foreign market and to push them to invest (Graham et al., 2009).

Significant differences in accounting standards can exacerbate this informative disadvantage. This is because financial disclosures are less understandable for the foreign investors who do not know the institutional, economic, legal, and accounting background where the entity that prepares the financial reports operates (Portes \& Rey, 2005; Van Nieuwerburgh \& Veldkamp, 2009; Chen et al., 2011). This situation can worsen if financial reports and local generally accepted accounting principles (GAAP) have low quality and are ambiguous.

Therefore, a process of accounting harmonisation/convergence with the adoption of global, high-quality accounting standards should increase the international mobility of capital by reducing information asymmetry (Seay, 2014). The willingness of achieving this objective is one of the main reasons justifying the diffusion of the IAS/IFRS around the world (IFRS Foundation, 2021a). 
As stated by previous research, the IAS/IFRS are in general of higher quality than the local GAAP (Barth et al., 2008; Ebaid, 2016; Key \& Kim, 2020). This higher quality should translate into higher understandability and transparency in financial information, allowing for the better understanding of the economic feature underlying the companies (Barth et al., 2012; Bhat et al., 2016; Kainth \& Wahlstrøm, 2021) and increasing the comparability of the information (Cascino \& Gassen, 2015). Moreover, the use of well-known accounting standards can increase foreign investor's confidence in their ability to assess the market and thus can lead them to invest more (Amiram, 2012).

There are other reasons that outline how the adoption of the IAS/IFRS can attract more international investors. Some studies have shown that countries that are IAS/IFRS adopters have easier access to a wider range of financial sources; so, they have a higher level of liquidity in the market, and, in the end, it is easier to raise capital to fund the companies (Coyring et al., 2007; Drake et al., 2012; Istiningrum, 2020). In addition, Bruggermann et al. (2010) observed that the trading activity conducted by single investors is increased because of the mandatory adoption of IAS/IFRS in numerous countries. This confirmed the idea that the strength of the disclosure system - thanks to better accounting standards - is positively associated with market development (Frost et al., 2006).

Some scholars have focused on the effects of IAS adoption and the cost of the debt and debt markets. For instance, Ozkaya (2018) found evidence that after the IFRS adoption in Turkey, firms in the sample have a significantly lower cost of debt after the adoption year. Florou and Kosi (2015) document positive economic consequences around the mandated IAS/IFRS adoption for corporate debt financing and, in particular, for bond financing. Some recent empirical analysis confirmed that the adoption of IAS/IFRS can help firms to access debt through a reduction in their opacity (Bertrand et al., 2021).

Also, the effects of IAS/IFRS adoption on the cost of equity can attract foreign investors. Different studies supported the idea that thanks to accounting harmonisation/convergence with the IAS/IFRS, the cost of equity decrease (Chan et al., 2009; Li, 2010; Castillo Merino et al., 2014; de Moura et al., 2020).

Therefore, considering the short literature review presented above, it is deduced that the general effects of the adoption of IAS/IFRS are positive. In particular, the reduction of information asymmetries and the improvement of some general economic conditions in the market (cost of debt, liquidity, cost of equity, etc.) could incentivise foreign investors in betting on the companies of the countries that are IAS/IFRS adopters. So, we can formulate the following hypotheses:

H1(a): The adoption of IAS/IFRS by the target country increases the Foreign Direct Investment (FDI) flows toward the target country.

H1(b): The adoption of IAS/IFRS by both countries involved in the operation increases the Foreign Direct Investment (FDI) flows among them.

At the beginning of the 2000s, a number of M\&A operations started a growing trend, especially in Europe and in Asia. In particular, the European Union (EU) became a very attractive market for foreign investors and, for the first time, the volume of M\&A operations made by European companies reached the level of the United States (US) M\&A figures (Moschieri \& Campa, 2014). Naturally, in the years after the financial crisis exploded in 2008, the number of M\&A decreased, but from 2014 the trend has once again become positive.

Which of the drivers that have made the EU a very attractive market, especially for M\&A? Broadly speaking, European Commission interventions to create a suitable area for acquisitions were very important (Sudarsanam, 2003; Bjorvatn, 2004). The institution of a common currency (euro), the creation of a common market and the introduction of a unique body of law for international transactions contributed to making the EU a centre of attraction for M\&A operations (Moschieri \& Campa, 2014).

M\&A operations are a strategic tool to promote the growth of a company (Cartwright \& Cooper, 1993; Saxena, 2012; Hossain, 2021). The main objectives are to get a more efficient allocation of the resources and to become more effective by exploiting production synergies (Davis-Friday \& Skaife, 2008; Kumar \& Sharma, 2019). Owing to the process of capital allocation in different business and geographic areas, a company diversifies its idiosyncratic risks (Rossi \& Volpin, 2004; Chen \& Yu, 2012; Wu \& Chiang, 2019).

However, it is necessary to note that the existing barriers among different countries - such as informative asymmetries, institutional disparities and differences in disclosure requirements generated by different accounting standards - are important elements that can limit the movement of capital and can negatively affect the volume of M\&A (Das \& Segupta, 2001; Bris \& Cabolis, 2008; Starks \& Wei, 2013; Cheng et al., 2015; Kashiwazaki et al., 2019). The recent adoption of IAS/IFRS in many countries is a good opportunity to understand the role that these accounting standards play in facilitating cross-border business activities (Ashbaugh \& Pincus, 2001; DeFond et al., 
2011; Florou \& Pope, 2012; Hong et al., 2014; Francis et al., 2016).

In particular, Yu and Wahid (2014) observe that differences in accounting standards among countries are an information cost charged to foreign investors, and it raises the risk of data misinterpretation. Accordingly, this can negatively affect the decisions about cross-border M\&A (Leuz, 2006; PwC, 2017). In fact, differences in accounting standards can add an idiosyncratic interference to the circulation of information, slowing down the investor's decisional process. So, foreign investors have to pay higher information costs if accounting standards are much different (Zhu, 2014), because they have to spend time and resources to interpret the financial reports of the target companies (Gehrig, 1993; Ball, 2006; Beneish et al., 2015). Therefore, as stated by Zhu (2014), it is possible to argue that a deviation from IAS/IFRS adoption could create informative disadvantages for acquirers, with negative effects towards counterparties in M\&A operations. Some studies remark that differences in accounting standards are associated in a negative way with flows arising from M\&A operations (Karolyi, 2006; Piotroski \& Srinivasan 2008; Leuz et al., 2009; Tan et al., 2011; Horton et al., 2013). It is shown that a growth of $1 \%$ in the difference among accounting standards of the two countries is accompanied by a reduction of $2 \%$ in bilateral M\&A (Zhu, 2014).

The process of accounting harmonisation carried on by the EU should reduce informative asymmetries and stimulate international business activities, such as cross-border M\&A (Ramanna \& Sletten, 2014; Louis \& Urcan, 2014).

So, in the light of the previous short literature review, we can propose the following hypothesis:

H2: The IAS/IFRS adoption has generated the growth of the M\&A value among listed companies in the EU market and companies residing in the 34 OECD member countries.

\section{Method}

To verify our hypotheses, we used two multiple linear regression (MLR) analyses. MLR is a statistical technique for estimating the relationship among variables which have reason and result relation; also, the main focus is to analyse the relationship between a dependent variable and some independent variables (Uyanık \& Güler, 2013). MLR is a widely used method within social science research (Tranmer \& Elliot, 2008) and is included in accounting (Luthan \& Satria, 2016). So, MLR represents the most suitable method to conduct our study.

With our first analysis, we wanted to explore the impact of IFRS adoption on FDIs, while with the second one we wished to investigate the relation among IFRS adoption and cross-border M\&A operations.

\subsection{Analysis 1: IFRS and FDI}

\subsubsection{Sample and Variables}

For the first analysis, the sample is represented by the 34 countries belonging to the OECD in 2015 (Note 1). This choice was based on the considerations that these countries are the most developed and they represent the majority percentage of the world economy. Moreover, for these nations, it is possible to find more reliable and comparable statistical data. Notably, this selection is coherent with previous research (Chen et al., 2014).

The time span for the observations was from 2003 to 2012. This time horizon includes 2005, the year in which the most of sample countries adopted IAS/IFRS. The presence of years before and after 2005 was very useful to better understand the impact of IAS/IFRS adoption.

The sample includes 7,268 observations.

The selected variables include the most important macroeconomic factors underlying each internationalisation process (Caroli, 2012). In particular, the dependent variable is the absolute value of the flows of FDIs among the countries in the sample $\left(\mathrm{FDI}_{\mathrm{IJ}}\right)$. Furthermore, the explanatory variables are: the gross domestic product (GDP) growth rate and GDP per capita growth rate $\left(\mathrm{GDP}^{\text {Growth_Investee }}\right.$ and GDPPerCapita $\left.{ }^{\text {Investeegrowth }}\right)$; inflation rate (InflationRate ${ }^{\text {Investee }}$ ); corporate income tax rate (IncomeTaxRate ${ }^{\text {Investee }}$ ); import and export volumes (LNImports ${ }^{\text {Investee }}$, LNExports $^{\text {Investee }}$ ); and the FDI flows of the countries in the sample to the rest of the world (LNFDI ${ }^{\text {InvesteeNetInflows }}$ ). In the end, the following dummy variables are considered: IFRS Investee (IFRS ${ }^{\text {Investee }}$ ); IFRS Investor (IFRS ${ }^{\text {Investor }}$ ) (Note 2); and IFRS both (IFRS ${ }^{\text {Both }}$ ) (they assume 0 in case of IFRS are not adopted, otherwise the value is 1). Information about these variables was collected using the OECD database (OECD.Stat).

3.1.2 Descriptive Statistics and Regression Model Formula

In Table 1, there are descriptive statistics. 
Table 1. Descriptive statistics - Analysis 1

\begin{tabular}{lcccccccc}
\hline & Average & $\begin{array}{c}\text { Standard } \\
\text { error }\end{array}$ & Median & Mode & $\begin{array}{c}\text { Standard } \\
\text { Deviation }\end{array}$ & $\begin{array}{c}\text { Sampling } \\
\text { Variance }\end{array}$ & Min & Max \\
\hline LNFDIij & 18.48 & 0.04 & 18.85 & 13.82 & 3.05 & 9.30 & 6.90776 & 26.12574 \\
IFRSBoth & 0.50 & 0.01 & 1 & 1 & 0.50 & 0.25 & 0 & 1 \\
IFRS Investor & 0.65 & 0.01 & 1 & 1 & 0.48 & 0.23 & 0 & 1 \\
IFRSInvestee & 0.63 & 0.01 & 1 & 1 & 0.48 & 0.23 & 0 & 1 \\
GDPGrowthInvestee & 0.02 & 0.00038 & 0.02 & 0.02 & 0.03 & 0.00 & -0.14720 & 0.10834 \\
InflationRateInvestee & 0.03 & 0.00027 & 0.02 & 0.03 & 0.02 & 0.00 & -0.04480 & 0.25296 \\
LNImports & 25.94 & 0.01 & 25.93 & 26.41 & 1.19 & 1.43 & 21.68910 & 28.64471 \\
LNExports & 25.96 & 0.01 & 26.01 & 26.52 & 1.18 & 1.39 & 21.57810 & 28.42807 \\
GDPPerCapitaGrowthInvestee & 0.01 & 0.00038 & 0.02 & 0.01 & 0.03 & 0.00104 & -0.14560 & 0.10924 \\
LNFDINetInflowsInvestee & 23.38 & 0.02 & 23.45 & 22.92 & 1.58 & 2.49 & 17.32850 & 27.32179 \\
CorporateIncomeTaxRate & 0.25 & 0.00077 & 0.26 & 0.30 & 0.07 & 0.00434 & 0.08500 & 0.36100 \\
\hline
\end{tabular}

As we can see in Table 1, some variables are transformed in their logarithms. This is because a non-linear relation is found among some explicative variables and the dependent variable (see Table 2 - 'Correlation analysis'), so the use of logarithms allows for the linearising of the relations. Correspondingly, in appendix A, there is Table 11 that shows the complete correlation analysis, considering all variables.

Table 2. Correlation analysis - Analysis 1

\begin{tabular}{lc}
\hline & FDIij \\
\hline FDIij & 1 \\
IFRSBoth & 0.009933882 \\
IFRS Investor & 0.026158807 \\
IFRSInvestee & 0.028070492 \\
GDPGrowthInvestee & -0.042961597 \\
InflationRateInvestee & -0.053140623 \\
ImportsInvestee & 0.206494977 \\
ExportsInvestee & 0.202138716 \\
GDPPerCapitaGrowthInvestee & -0.054040391 \\
FDINetInflowsInvestee & 0.301938076 \\
FDIInvestee/FDIWorld & 0.276794188 \\
CorporateIncomeTaxRate & 0.056636612 \\
\hline
\end{tabular}

Now, it is possible to show the regression model adopted (Borra, Di Ciaccio, 2004; Piccolo, 2010):

$$
\begin{aligned}
& \log \left(\mathrm{FDI}_{\mathrm{IJ}}\right)=\beta_{0}+\beta_{1} \text { IFRS }^{\text {Investee }}+\beta_{2} \mathrm{GDP}_{\text {growth }}^{\text {Investee }}+\beta_{3} \text { InflationRate }^{\text {Investee }}+\beta_{4} \text { LNImports }^{\text {Investee }}+ \\
& \beta_{5} \text { LNExports }^{\text {Investee }}+\beta_{6} \text { GDPPerCapita }_{\text {growth }}^{\text {Investee }}+\beta_{7} \text { LNFDI Inestee }_{\text {NetInflows }}+\beta_{9} \text { IncomeTaxRate }^{\text {Investee }}+\varepsilon_{\mathrm{i}}
\end{aligned}
$$

We outline that, to define regression parameters, sample regression coefficients $\left(b_{0}, b_{1}, \ldots b_{n}\right)$ are used such as the estimator of population parameters $\left(\beta_{0}, \beta_{1}, \beta_{2}, \ldots, \beta_{\mathrm{n}}\right)$

\subsection{Analysis 2: IFRS and Cross-Border M\&A}

\subsubsection{Sample and Variables}

For the second analysis, it was considered 1,164 M\&A operations made by European-listed companies towards target companies located in the 34 OECD member countries with a value higher than 1 million USD. The time horizon is from January 2005 (the year of the first mandatory adoption of IAS/IFRS in Europe) to December 2015. These data were collected from the database Thomson Reuters EIKON. 
For this study, the selection of variables was conducted considering suggestions resulting from previous research (Chen et al., 2015; Di Giovanni, 2005). Therefore, the dependent variable is the total amount of M\&A operations which occurred among sample countries $\left(\right.$ ValueM\& $\left.\mathrm{A}_{\mathrm{IJ}}\right)$. While, for the explanatory variables, we considered both macroeconomics and financial factors. About macroeconomic factors, we took into account the GDP growth rate (GDP Growth ${ }^{\text {TargetNation }}$ ); import and export volumes (in percentage to GDP) (Exports ${ }^{\text {TargetNation }}$ and Imports ${ }^{\text {TargetNation }}$ ); and the adoption of common currency (the euro) (Euro Adopters ${ }^{\text {TargetNation }}$ ). This last variable is useful to understand how the absence of an exchange rate can influence foreign investment decisions. It is a dummy variable, and it is 1 if the country is a euro adopter, otherwise the value is 0 . Moreover, we also considered the variable 'IFRS_Target Nation' that allows us to understand if the IFRS adoption affects the foreign investment decisions of the purchasing country (it is a dummy variable, and it is 1 if the country is an IFRS adopter, otherwise the value is 0 ). About the financial factors, we included the net financial transaction of total economy (in percentage to the GDP) (Net financial transaction $^{\text {TargetNation }}$ ) and it helped us to understand if the country was on credit or debit; the balance of the financial worth for the institutional sectors of the economy (in percentage to the GDP) (Financial net worth ${ }^{\text {TargetNation }}$ ), and it represents a summary of financial wealth of the country; the short- and long-term interest rate (they are included to better represent the financial market of the country) (Long-term interest rate ${ }^{\text {TargetNation }}$ and Short-term interest rate $^{\text {TargetNation }}$ ); and the debt of the economy (Debt of total economy ${ }^{\text {TargetNation }}$ ). Data about these variables were collected from OECD.Stat and the World Database Indicator.

3.2.2 Descriptive Statistics and Regression Model Formula

In Table 3, there are descriptive statistics.

Table 3. Descriptive statistics - Analysis 2

\begin{tabular}{|c|c|c|c|c|c|c|c|c|}
\hline & Average & $\begin{array}{c}\text { Standard } \\
\text { error }\end{array}$ & Median & Mode & $\begin{array}{l}\text { Standard } \\
\text { Deviation }\end{array}$ & $\begin{array}{l}\text { Sampling } \\
\text { Variance }\end{array}$ & Min & Max \\
\hline LNValue_M\&A & 19.339 & 0.069555 & 19.384 & 13.82 & 2.372022 & 5.626488 & 13.8155 & 25.71112 \\
\hline IFRS_Target Nation & 0.8977 & 0.008891 & 1 & 1 & 0.303201 & 0.091931 & 0 & 1 \\
\hline $\begin{array}{l}\text { Net financial transaction of } \\
\text { total economy (\% of } \\
\text { GDP)_Target Nation }\end{array}$ & -0.007 & 0.001813 & -0.0191 & -0.046 & 0.061831 & 0.003823 & -0.9306 & 0.1618 \\
\hline $\begin{array}{l}\text { Financial net worth of total } \\
\text { economy ( } \% \text { of } \\
\text { GDP)_Target Nation }\end{array}$ & -0.153 & 0.012728 & -0.1164 & -0.544 & 0.434049 & 0.188398 & -2.0767 & 1.6754 \\
\hline $\begin{array}{l}\text { Long-term interest } \\
\text { rate_Target Nation }\end{array}$ & 0.0373 & 0.000435 & 0.0376 & 0.034 & 0.014845 & 0.00022 & 0.005 & 0.225 \\
\hline $\begin{array}{l}\text { Short-term interest } \\
\text { rate_Target Nation }\end{array}$ & 0.0261 & 0.000544 & 0.0297 & 0.031 & 0.018565 & 0.000345 & -0.0012 & 0.124 \\
\hline $\begin{array}{l}\text { Debt of total economy (\% } \\
\text { of GDP)_Target Nation }\end{array}$ & 7.0569 & 0.262763 & 6.2861 & 0.868 & 8.960939 & 80.29843 & 0.7672 & 94.9459 \\
\hline $\begin{array}{l}\text { GDP } \quad \text { Growth_Target } \\
\text { Nation }\end{array}$ & 0.019 & 0.000806 & 0.024 & 0.036 & 0.027478 & 0.000755 & -0.083 & 0.094 \\
\hline $\begin{array}{l}\text { LNFDI Net } \\
\text { Inflows_Target Nation }\end{array}$ & 23.93 & 0.051302 & 24.22 & 24.78 & 1.749534 & 3.060869 & 17.3285 & 27.32179 \\
\hline $\begin{array}{l}\text { Export (\% of GDP)_Target } \\
\text { Nation }\end{array}$ & 0.4259 & 0.008106 & 0.3718 & 0.213 & 0.276446 & 0.076422 & 0.03196 & 2.0327 \\
\hline $\begin{array}{ll}\text { Imports } \quad(\% & \text { of } \\
\text { GDP)_Target Nation } & \end{array}$ & 0.4028 & 0.006767 & 0.326 & 0.214 & 0.230757 & 0.053249 & 0.0326 & 1.7088 \\
\hline $\begin{array}{l}\text { Euro Adopters_Target } \\
\text { Nation }\end{array}$ & 0.5193 & 0.014657 & 1 & 1 & 0.499841 & 0.249841 & 0 & 1 \\
\hline
\end{tabular}

As among dependent variable and explicative variables, there is sometimes no linear relation (see Table 4 'Correlation analysis'), some variables are transformed in their logarithms (in Appendix B there is Table 12 that shows the complete correlation analysis, considering all variables). 
Table 4. Correlation analysis - Analysis 2

\begin{tabular}{lc}
\hline & Value M\&A \\
\hline Value M\&A & 1 \\
IFRS_Target Nation & 0.050539676 \\
Net financial transaction of total economy (\% of GDP)_Target Nation & -0.035620784 \\
Financial net worth of total economy (\% of GDP)_Target Nation & 0.044240614 \\
Long-term interest rate_Target Nation & 0.009329527 \\
Short-term interest rate_Target Nation & 0.051987115 \\
Debt of total economy (\% of GDP)_Target Nation & 0.003385791 \\
GDP Growth_Target Nation & 0.076190855 \\
FDI net inflows_Target Nation & 0.131975222 \\
Export (\% of GDP)_Target Nation & -0.024323809 \\
Imports (\% of GDP)_Target Nation & -0.011713273 \\
Euro Adopters_Target Nation & -0.006982517 \\
\hline
\end{tabular}

Now, it is possible to show the regression model adopted (Borra \& Di Ciaccio, 2004; Piccolo, 2010):

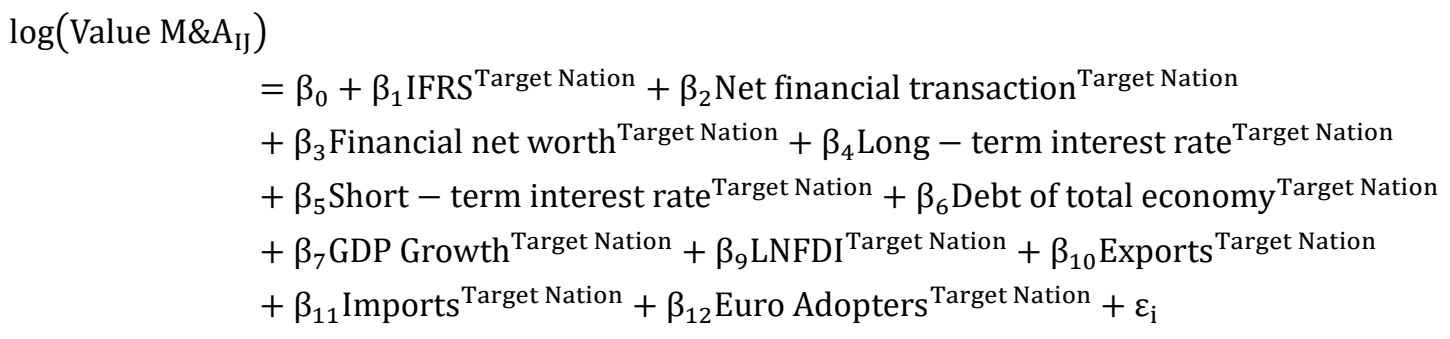

\section{Results and Robustness Tests}

4.1 Analysis 1. The Relation among IAS/IFRS Adoption and FDI Flows

In Table 5, we can find the results of multiple regression analysis.

Table 5. Multiple regression analysis (paying attention to IFRS ${ }^{\text {Investee }}$ ) - Analysis 1

\begin{tabular}{lcccc}
\hline & Coefficients & Standard Error & Test statistic (t test) & Significant Value \\
\hline Intercept & -3.841114354 & 0.783118962 & -4.90489254 & $9.55121 \mathrm{E}-07$ \\
IFRSInvestee & $\mathbf{0 . 4 1 4 8 0 5 7 6 3}$ & $\mathbf{0 . 0 7 1 3 5 9 9 0 5}$ & $\mathbf{5 . 8 1 2 8 6 8 7 5 8}$ & $\mathbf{6 . 4 0 1 3 4 E - 0 9}$ \\
GDPGrowthInvestee & 13.59590653 & 5.361410245 & 2.535882522 & 0.011237231 \\
InflationRateInvestee & -0.139311503 & 1.623384978 & -0.085815444 & 0.931615496 \\
LNimports & -0.065795499 & 0.236244724 & -0.278505686 & 0.780632134 \\
LNExports & 0.599911005 & 0.239333836 & 2.506586673 & 0.012212007 \\
GDPPerCapitaGrowthInvestee & -15.97074327 & 5.325627159 & -2.998847422 & 0.002719219 \\
LNFDINetInflowsInvestee & 0.380270459 & 0.030429568 & 12.49674209 & $1.79939 \mathrm{E}-35$ \\
CorporateIncomeTaxRate & -2.976604057 & 0.55576922 & -5.355827471 & $8.77781 \mathrm{E}-08$
\end{tabular}

The inclination of this regression model is positive $\left(b_{1}=0,4148\right)$, and it means that the adoption of IAS/IFRS by target country is beneficial. Therefore, the fact that the target country uses IAS increases the volume of foreign investments by $41.48 \%$.

So, it is possible to confirm our first hypothesis, $H 1(a)$.

To be sure about these results, it is important to understand the adequacy of the adopted regression model. As suggested by some scholars (Piccolo, 2010), we conducted a residual analysis of the considered variables. This 
procedure helps us to understand if there is a recognisable structure among dependent and explanatory variables. If this structure exists, it means dependent variables and explanatory variables are linked by a non-linear relation and, in this case, the adopted regression model would not be suitable. The residual analysis confirms the adequacy of the regression model chosen for this study. Notably, in Figure 1, we can see the track of residues for the most important variable IFRS ${ }^{\text {Investee }}$.

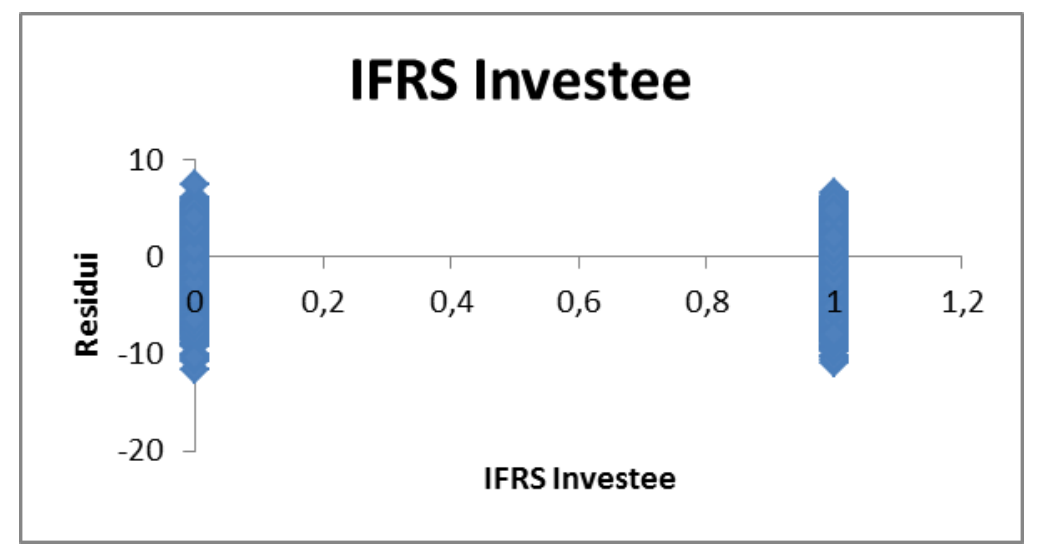

Figure 1. Track of residues - explanatory variable IFRS ${ }^{\text {Investee }}$

Now, after the focus on the IFRS ${ }^{\text {Investee }}$ variable, it was appropriate to verify if there was a significant relation among the dependent variable and the whole of the explicative variables.

The null hypothesis is structured as follows: $H_{0}: \beta_{1}=\beta_{2}=\beta_{3}=\beta_{4}=\beta_{5}=\beta_{6}=\beta_{7}=0$ (there is no linear relation among the dependent variable and the explanatory variables).

The alternative hypothesis is structured as follows: $\mathrm{H} 1$ : at least one $\beta_{\mathrm{j}} \neq 0$ (there is a linear relation among the dependent variable and at least one explanatory variable).

To make this analysis, an $F$ test had to be conducted (Borra \& Di Ciaccio 2004; Piccolo, 2010). The $F$ test is the ratio among the average of squares of the regression and the average of squares of the errors. The decision rule is: $\mathrm{H}_{0}$ is rejected if $F>F_{u}$ where $F_{u}$ is the critical value of the tail of the right of an $F$ distribution with $\mathrm{p}$ and n-p-1 degrees of freedom; otherwise $\mathrm{H}_{0}$ is accepted. Now, we show the analysis of variance (ANOVA) table for this study.

Table 6. ANOVA table to test the significance of the whole regression coefficients

\begin{tabular}{lccccc}
\hline & Degrees of freedom & Sum Squares & Mean Squares & F & Significance F \\
\hline Regression & 8 & 9537.695445 & 1192.211931 & 149.1351168 & $3.1157 \mathrm{E}-233$ \\
Residual & 7258 & 58021.70794 & 7.994173042 & & \\
Total & 7266 & 67559.40338 & & & \\
\hline
\end{tabular}

Considering 0.05 as the level of significance and observing Table 6 , we note that the critical value of $F$ distribution with 8 and 7,258 degrees of freedom is about 2.01. Since $F$ from multiple linear regression is 149.14, we have that $F>$ $F_{u}$ and so it is possible to reject $\mathrm{H}_{0}$ and conclude that there is a linear relation among the dependent variable and at least one independent variables.

It is appropriate to present another test on the hypothesis about the inclination of the regression line, to verify the significance of the relation among $\mathrm{X}$ and $\mathrm{Y}$ and to build a confidence interval to assess the inclination of the regression line. To do this, we used a test statistic to verify the hypothesis $\beta_{1}=0$ that, in our regression model, is represented by this formula:

$$
\mathrm{t}=\frac{\mathrm{b}_{\mathrm{k}}}{\mathrm{S}_{\mathrm{b}_{\mathrm{k}}}}
$$

where:

- $\quad b_{\mathrm{k}}$ : it is the inclination of $Y$ regarding k variable maintaining constant other variables;

- $\quad S_{\mathrm{bk}}$ : it is the standard error of regression coefficient $b_{\mathrm{k}}$; 
- $\quad \mathrm{t}$ : it is the statistic with distribution $t$ and $n-p-l$ degrees of freedom.

Also in this case, we have the null hypothesis $\left(\mathrm{H}_{0}\right)$ and the alternative hypothesis $\left(\mathrm{H}_{1}\right)$ :

$$
\begin{aligned}
& \mathrm{H}_{0}: \beta_{1}=0 \\
& \mathrm{H}_{1}: \beta_{1} \neq 0
\end{aligned}
$$

In Table 5, the test statistic results ( $\mathrm{t}$ test) are reported for each variable. For variable $X_{1}$ (IFRS ${ }^{\text {Investee }}$ ), $t$ test is equal to 5.81. Considering 0.05 as the level of significance, it is possible to assess value of $t$ test for 7,258 degrees of freedom and they are equal to +1.6450 and -1.6450 . Therefore, as $t_{\mathrm{X} 1}(5.81)>t_{7,258}(1.6450)$, it is possible to reject the null hypothesis $\left(\mathrm{H}_{0}\right)$. So, we can conclude that there is a significant relation among the $\mathrm{X}_{1}$ variable (adoption of IAS/IFRS) and the FDI flows of among country $i$ and country $j$.

Following the same logic adopted before, we conducted another multiple regression analysis to consider also the explicative variable represented by the adoption of IAS/IFRS by both target and investor country (IFRS ${ }^{\text {Both }}$ ). In Table 7 we present the results.

Table 7. Multiple regression analysis (paying attention to IFRS ${ }^{\text {Both }}$ ) - Analysis 1

\begin{tabular}{lcccc}
\hline & Coefficients & Standard Error & Test Statistic (t test) & Significant Value \\
\hline Intercept & -3.952669171 & 0.785069608 & -5.034800904 & $4.8987 \mathrm{E}-07$ \\
IFRSBoth & $\mathbf{0 . 5 6 2 0 4 7 1 4 5}$ & $\mathbf{0 . 1 5 5 0 2 2 1 8 7}$ & $\mathbf{3 . 6 2 5 5 9 1 6 4 3}$ & $\mathbf{0 . 0 0 0 2 9 0 2 7 6}$ \\
IFRS Investor & -0.130428952 & 0.114524746 & -1.138871349 & 0.254794415 \\
IFRSInvestee & 0.016802981 & 0.119303401 & 0.140842429 & 0.887998334 \\
GDPGrowthInvestee & 14.74948205 & 5.427896689 & 2.717347601 & 0.006596363 \\
InflationRateInvestee & -0.210498695 & 1.622392584 & -0.129745844 & 0.896771107 \\
LNimports & -0.034213927 & 0.237941484 & -0.143791351 & 0.885669226 \\
LNExports & 0.572544841 & 0.240374625 & 2.381885524 & 0.017249872 \\
GDPPerCapitaGrowthInvestee & -17.18166251 & 5.40289156 & -3.180086499 & 0.001478505 \\
LNFDINetInflowsInvestee & 0.383843136 & 0.030407748 & 12.62320173 & $3.76594 \mathrm{E}-36$ \\
CorporateIncomeTaxRate & -3.115526416 & 0.572282276 & -5.444037925 & $5.37902 \mathrm{E}-08$ \\
\hline
\end{tabular}

We can see that the coefficient of the variable IFRS ${ }^{\text {Both }}$ is positive (0.56). It means that we can expect growth with regard to foreign investment flow if both countries are IAS/IFRS adopters.

Therefore, we can confirm hypothesis $H 1(b)$.

As we did earlier, it is useful to make a test to confirm that there is a significant relation among the dependent variable and explicative variables. Also in this case, we adopted an $F$ test to verify the hypothesis (null hypothesis $\mathrm{H}_{0}$ : there is no linear relation among dependent variable and explanatory variables; and alternative hypothesis $\mathrm{H}_{1}$ : there is a linear relation among dependent variable and at least one explanatory variable). Table 8 presents the ANOVA table for this analysis.

Table 8. ANOVA table to test the significance of the whole regression coefficients

\begin{tabular}{lccccc}
\hline & Degree of Freedom & Sum Squares & Mean Squares & F & Significance F \\
\hline Regression & 10 & $9,682.496657$ & 968.2496657 & 121.3889956 & $5.7134 \mathrm{E}-235$ \\
Residual & 7,256 & $57,876.90673$ & 7.976420442 & & \\
Total & 7,266 & 67559.40338 & & &
\end{tabular}

Considering 0.05 as the level of significance, we can assess that the critical value for an $F$ distribution with 10 and 7,256 degrees of freedom is about $1.88\left(F_{u}\right)$ and since $F=121.389, F>F_{u}$ therefore it is possible to reject $\mathrm{H}_{0}$. We can conclude that there is a linear relation among at least one of the explicative variables and the foreign investment flow among country $i$ and country $j$.

The next passage is to adopt a test statistic to verify the significance of the relation among $\mathrm{X}$ and $\mathrm{Y}$ and to build a confidence interval to assess the inclination of the regression line. In Table $7, \mathrm{t}$-test results are reported for each variable. Also in this case, we considered both the null and the alternative hypothesis $\left(\mathrm{H}_{0}\right.$ and $\left.\mathrm{H}_{1}\right)$ : 


$$
\begin{aligned}
& \mathrm{H}_{0}: \beta_{1}=0 \\
& \mathrm{H}_{1}: \beta_{1} \neq 0
\end{aligned}
$$

The value of $t$ test is about 3.63. Considering 0.05 as the level of significance, it is possible to assess the value of $t$ test for 7,256 degrees of freedom and they are equal to +1.6450 and -1.6450 . Therefore, as $t_{\mathrm{X} 1}(3.63)>t_{7,256}(1.6450)$, it is possible to reject the null hypothesis $\left(\mathrm{H}_{0}\right)$. So, we can conclude that there is a significant relation among the $\mathrm{X}_{1}$ variable (adoption of IAS/IFRS by both countries) and the flow of FDIs.

\subsection{Analysis 2 - The Adoption of IAS/IFRS and M\&A Operations}

In Table 9, we can see the results produced from the application of the regression model.

\begin{tabular}{|c|c|c|c|c|}
\hline & Coefficients & Standard Error & Test Statistic (t test) & Significant Value \\
\hline Intercepts & 14.21257489 & 1.149247869 & 12.36684903 & $4.48935 \mathrm{E}-33$ \\
\hline IFRS_Target Nation & 0.59404679 & 0.273028368 & 2.175769481 & 0.029775397 \\
\hline $\begin{array}{l}\text { Net financial transaction of total } \\
\text { economy (\% of GDP)_Target Nation }\end{array}$ & -0.416172709 & 1.410411773 & -0.295071778 & 0.767992263 \\
\hline $\begin{array}{l}\text { Financial net worth of total economy } \\
\text { (\% of GDP)_Target Nation }\end{array}$ & 0.464310502 & 0.20636209 & 2.249979644 & 0.02463852 \\
\hline Long-term interest rate_Target Nation & 8.815435848 & 6.136000699 & 1.436674518 & 0.15108225 \\
\hline Short-term interest rate_Target Nation & 3.575156988 & 4.981130469 & 0.717740081 & 0.473063208 \\
\hline $\begin{array}{l}\text { Debt of total economy }(\% \text { of } \\
\text { GDP }) \text { Target Nation }\end{array}$ & 0.011851728 & 0.011666455 & 1.01588084 & 0.309899625 \\
\hline GDP Growth_Target Nation & 12.29233767 & 2.91641347 & 4.214881669 & $2.69471 \mathrm{E}-05$ \\
\hline LNFDI Net Inflows_Target Nation & 0.180494661 & 0.045211178 & 3.992257417 & $6.95919 \mathrm{E}-05$ \\
\hline Export (\% of GDP)_Target Nation & 0.442664546 & 0.782365419 & 0.565802802 & 0.571638125 \\
\hline Imports ( $\%$ of GDP)_Target Nation & -1.775509295 & 0.973961434 & -1.822977003 & 0.068566178 \\
\hline Euro Adopters_Target Nation & 0.249651613 & 0.156057462 & 1.599741586 & 0.109930355 \\
\hline R squared IFRS_Target Nation $_{\text {s. }}$ & 0.054298258 & & & \\
\hline
\end{tabular}

Table 9. Multiple regression analysis - Analysis 2

As we can see in Table 9, the coefficient $\mathrm{b}_{1}$ of the variable 'IFRS_Target Nation' is about 0.59. This means that the adoption of IAS/IFRS leads to the growth of the value of M\&A operations by a percentage equal to 59.4.

So, we have confirmed our hypothesis H2: The IAS/IFRS adoption has generated a growth of the M\&A value among listed companies in the EU market and companies residing in the 34 OECD member countries.

To verify the adequacy of the regression model we used, it was useful to make a residual analysis of the considered variables (as conducted in Analysis 1). Figure 2 shows the track of residues for the most important variable, IFRS_Target Nation. As there is not an identifiable structure among the dependent variable and the explicative variables, we can confirm the adequacy of the regression model adopted and the validity of the results found. 


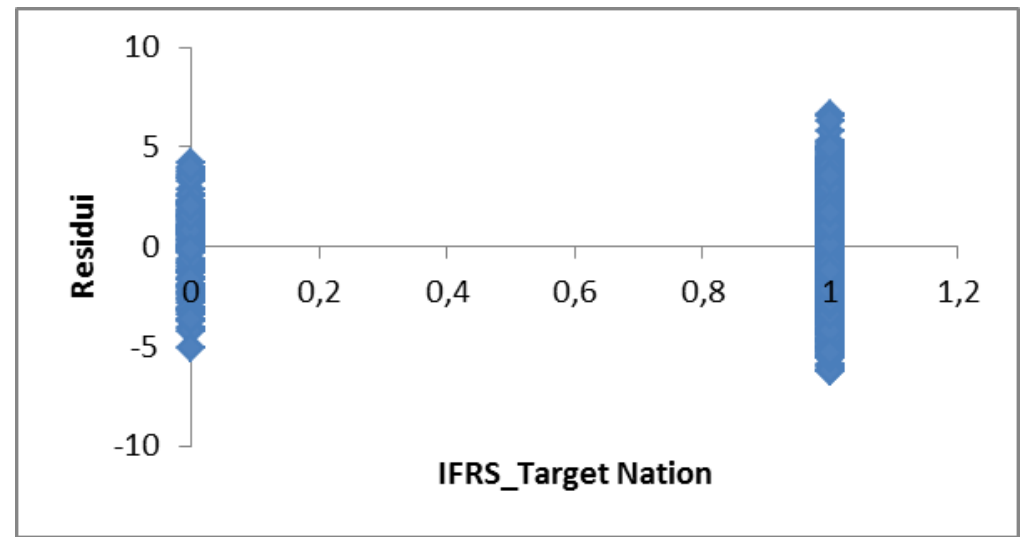

Figure 2. Track of residues - explanatory variable IFRS_Target Nation

Similar to Analysis 1, it was important to verify if there was a significant relation among the dependent variable (Value M\&A) and the whole of explicative variables.

The null hypothesis is structured as follows: $\beta_{1}=\beta_{2}=\beta_{3}=\beta_{4}=\beta_{5}=\beta_{6}=\beta_{7}=\beta_{8}=\beta_{9}=\beta_{10}=\beta_{11}=\beta_{12}=0$ (there is not a linear relation among the dependent variable and the explanatory variables).

The alternative hypothesis is structured as follows: $\mathrm{H} 1$ : at least one $\beta_{\mathrm{j}} \neq 0$ (there is a linear relation among the dependent variable and at least one explanatory variable).

To test these hypotheses, an $F$ test was conducted, and the results are presented in Table 10.

Table 10. ANOVA table to test the significance of the whole regression coefficients

\begin{tabular}{lccccc}
\hline & Degrees of Freedom & Sum Squares & Mean Squares & F & Significance F \\
\hline Regression & 11 & 355.0008652 & 32.27280593 & 6.007784527 & $1.33343 \mathrm{E}-09$ \\
Residual & 1151 & 6182.978011 & 5.37183146 & & \\
Total & 1162 & 6537.978876 & & &
\end{tabular}

The decision rule requires that $\mathrm{H}_{0}$ is rejected if $F>F_{u}$, where $F_{u}$ is the critical value of the tail of the right of an $F$ distribution with $\mathrm{p}$ and n-p-1 degrees of freedom; otherwise $\mathrm{H}_{0}$ is accepted. Considering 0.05 as the significance level, we can assess that the critical value for an $F$ distribution with 11 and 1,151 degrees of freedom is about 1.83 $\left(F_{u}\right)$ and since $F=6.0078, F>F_{u}$ and therefore it is possible to reject $\mathrm{H}_{0}$. We can conclude that there is a linear relation among at least one of the explicative variables and the value variation of M\&A operations.

Now, it is possible to test the eventual influence that the IFRS_Target Nation variable exerts on the dependent variable (Value $M \& A$ ). Therefore, we proceeded with a test statistic to verify the hypotheses. Also in this case, we had the null hypothesis and the alternative hypothesis:

$\mathrm{H} 0: \beta 1=0$

$\mathrm{H} 1: \beta 2 \neq 0$

Considering 0.05 as level of significance, it was possible to assess the value of $t$ test for 1,162 degrees of freedom and they were equal to +1.645 and -1.645 . Therefore, as $t$ test of the variable IFRS_Target Nation is about 2.1758 (as shown in Table 9), we have that $t_{\mathrm{X} 1}(2.1758)>t_{1,162}(1.645)$. It means that there is a significant relation among the variable IFRS_Target Nation and the dependent variable Value $M \& A$. Therefore, it is possible to reject the null hypothesis $\left(\mathrm{H}_{0}\right)$. So, we can conclude that there is a significant relation among the $\mathrm{X}_{1}$ variable (adoption of IAS/IFRS) and the growth of the value of M\&A operations.

\section{Interpretation of the Results}

\subsection{Analysis 1: IFRS and FDI}

Data emerging from the statistical analysis show that the adoption of IAS/IFRS has a positive impact on the FDIs among countries.

An initial explanation for this phenomenon is that the adoption of high-quality accounting standards allows for better financial information; accordingly, this reduces information asymmetry for foreign investors, allowing them to find 
easier opportunities for value creation and gaining their trust in the market. So, foreign investors are encouraged to diversify their financial portfolio which then generates a virtuous growth circle (Amiram, 2012; Akisik et al., 2020). Moreover, the process of accounting harmonisation positively affects the capital market, increases the liquidity and, consequently, reduces the cost of capital (Daske et al., 2008; Li, 2010; Daske et al., 2013; de Moura et al., 2020).

However, as in the adopted regression analysis, we considered various explicative variables. Specifically, it is useful to assess the coefficient of determination $\left(\mathrm{R}^{2}\right)$ to understand how much of variability of the $\mathrm{Y}$ is explained by independent variables (Borra \& Di Ciacci, 2003; Piccolo, 2010). $\mathrm{R}_{\mathrm{Y}}^{2}$ is given by the ratio among the sum of the squares of the regression and the total sum of squares. In our analysis we found:

$$
\begin{gathered}
\mathrm{R}_{\text {YInvestee }}^{2}=0,1412 \\
\mathrm{R}_{\text {YBoth }}^{2}=0,1433
\end{gathered}
$$

This means that these explicative variables explain, respectively, the $14.12 \%$ and $14.33 \%$ of the analysed phenomenon.

Considering the previous academic literature, a reason for these relatively low rates could depend on the chosen sample. In fact, as we explained above, we selected the 34 OECD member countries in 2015 for our study, but since the 2000s, other countries have appeared in the international market and they have attracted a lot of capital and investments (Caroli, 2012; Rahmani \& Motamedi, 2018). In particular, we can consider the entry of China into the World Trade Organization (WTO) which means that 1.3 billion people entered the international exchange system. Notably, this number is higher than the population of all OECD member countries. Moreover, other so-called developing countries opened up to foreign companies, incentivising corporations of developed countries to outsource their business to decrease their costs. Therefore, considering the average of FDIs in the period from 2000 to 2012, among the first 20 target countries, the data show that 9 of them are developing countries (World Bank, 2021). So, it can be sustained that taking into account also developing countries, the $\mathrm{R}_{\mathrm{Y}}^{2}$ could be higher. Nevertheless, to conduct our analysis, we considered more appropriate a sample with only the OECD member countries because, in the time horizon adopted in the study, most of them had already ended the accounting harmonisation process. On the contrary, the majority of developing countries had not yet ended the process of IAS/IFRS adoption.

\subsection{Analysis 2: IFRS and Cross-Border M\&A}

The regression analysis shows that the adoption of IAS/IFRS by a target company is a factor that makes this one more attractive, and thus, foreign companies are incentivised to set up M\&A operations.

However, also in this case, it is useful to analyse the coefficient of determination $\mathrm{R}^{2}$.

As visible in Table $9, \mathrm{R}^{2}$ is about $5.43 \%$. It is a low rate, but nevertheless, we have to consider the following aspects that help us to better understand this value.

First of all, it should be noted the role that the capital market has in the EU. In confrontation with the rest of the world, European finance is more based on the financial institutions (such as banks) rather than the equity market. Indeed, in 2015, for European companies bank credits were about $80 \%$ of their total financial assets and only $20 \%$ were bonds or equity. So, in the EU, the companies - above all, small and medium-sized enterprises (SMEs) - are mainly financed with bank loans. Subsequently, this dependency made the EU economy more vulnerable when banks reduced their propensity to lend money after the 2007-2008 financial crisis (Quaglia et al., 2016).

Another point to note is the access by companies and people to the European capital market. As stated by Quaglia et al. (2016), there is a relevant difference among nations about external funding of non-financial companies. Figure 3 shows how the European capital market is very fragmented. 


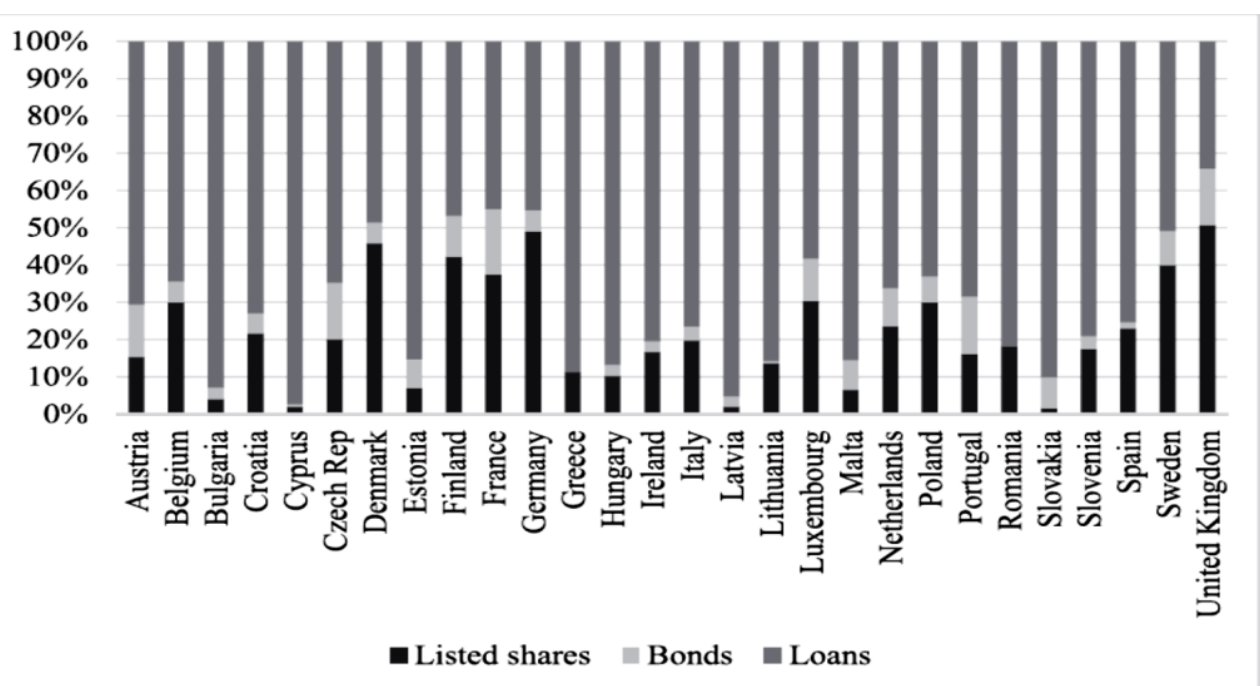

Figure 3. Structure of liabilities of non-financial companies in the EU in 2015 (Quaglia et al., 2016)

It was clear that this aspect could affect our regression analysis because we considered M\&A operations occurred among listed companies working in a market that is still inefficient and underdeveloped. As evidence of these issues, the EU Commission created the Capital Markets Union (CMU) programme in order to encourage a more efficient and efficacious development of the capital market, so that it could be used by SMEs as a useful financial source alternative to the banks (European Commission, 2015).

Next, it is important to note that the time horizon considered for this research also included the years following one of the most important financial crises of the last decades. Therefore, listed markets experienced a price collapse of shares, the volatility was increased, and financial institutions had big liquidity problems (Cheung et al., 2014). This difficult situation generated mistrust in investors and companies, leading to a significant, general reduction of investment operations. This is another fact that could affect our research and its results. However, it is useful to state that the accounting harmonisation process could be a factor to help the economic recovery after the crises, because it reduces the information asymmetry and makes financial statements more comparable, thus incentivising investors to operate and reduce the cost of capital (Marcellina \& Angela, 2018; Turki et al., 2020).

\section{Discussion}

Previous studies showed that the accounting harmonisation process could have very positive consequences on different economic aspects. The adoption of high-quality accounting standards - such as IAS/IFRS - improves the accuracy and comprehensibility of financial information, helping professional and non-professional investors in their decision-making (Diamond \& Verrecchia, 1991; Leuz \& Verrecchia, 2000; Biddle et al., 2009; Roychowdhury et al., 2019). Moreover, the increase of information transparency can incentivise managers to have a more investor-oriented approach, thus reducing opportunistic behaviour (Ball \& Shivakumar, 2005; Shin \& Oh, 2017) and agency costs (Bushman \& Piotroski, 2006; Nejad et al., 2020). In addition, the adoption of common accounting language can improve the trading in the debt market, making for easier access to bank loans (Ball, 2006; Balsmeier \& Vanhaverbeke, 2018).

Another important area to investigate is the role of accounting harmonisation in companies' internationalisation. So, to contribute to the very interesting topic just mentioned, our aim was to analyse the process of accounting harmonisation through the adoption of IAS/IFRS to see if it affects the internationalisation process. To do this, two multiple regression analysis were created. Accordingly, the first analysis considers the relation of the adoption of IAS/IFRS and FDIs and the second analysis takes into account the relation among the adoption of IAS/IFRS and cross-border M\&A operations. In fact, FDIs and cross border M\&A operations are considered variables that are able to represent the internationalisation phenomenon.

This study tries to give a theoretical contribution, showing that the adoption of IAS/IFRS - and so the accounting harmonisation process - has a positive impact on internationalisation. The results of the analysis outline that the adoption of IAS/IFRS helps the growth of FDI flows and also promotes the value of cross-border M\&A operations.

Moreover, this study can be very useful to policymakers and accounting regulators, incentivising them to start (or strengthen) the harmonisation/convergence process with the IAS/IFRS. Furthermore, managers of the corporations 
could find this study useful as our results can suggest to them to take into account the idea of adopting IAS/IFRS - if allowed in a voluntarily way - to facilitate the internationalisation process of their company.

Our research is not free from limitations. With regard to Analysis 1 (IFRS-FDI), the selected sample that only considers the 34 countries that were OECD members in 2015 can affect the relatively low R squared found, as explained in the sections of 'Results interpretations'. Indeed, during the 2000s, new and important countries - not OECD members - opened their markets to international investors and they attracted a significant amount of private funds and investments. These countries were not considered in our analysis because most of them were only at the beginning of the IAS/IFRS convergence/harmonisation process during the time horizon we considered. Nevertheless, this is a great opportunity for further studies because when developing countries are IAS/IFRS adopters, they could be included in studies similar to this one in order to expand the sample and enhance the insights. About Analysis 2 (IFRS-M\&A cross-border operations), the low R squared found can be due to the fact that the European capital market was still fragmented and undeveloped and, moreover, the time horizon includes years when the economy was very affected by the financial crisis which exploded in 2008. So, this study has revealed interesting results considering the specific features underlying the European capital market during the time span examined. Finally, in the future, when the European capital market is more mature and the economic cycle is more normalised, other scholars could replicate a similar study to try getting more significant results.

\section{References}

Akisik, O., Gal, G., \& Mangaliso, M. P. (2020). IFRS, FDI, economic growth and human development: The experience of Anglophone and Francophone African countries. Emerging Markets Review, 45, 100725. https://doi.org/10.1016/j.ememar.2020.100725

Amiram, D. (2012). Financial information globalization and foreign investment decisions. Journal of International Accounting Research, 11(2), 57-81. https://doi.org/10.2308/jiar-50282

Ashbaugh, H., \& Pincus, M. (2001). Domestic accounting standards, international accounting standards, and the predictability of earnings. Journal of accounting research, 39(3), 417-434. https://doi.org/10.1111/1475-679X.00020

Ball, R. (2006). International Financial Reporting Standards (IFRS): pros and cons for investors. Accounting and business research, 36(sup1), 5-27. https://doi.org/10.1080/00014788.2006.9730040

Ball, R., \& Shivakumar, L. (2005). Earnings quality in UK private firms: comparative loss recognition timeliness. Journal of accounting and economics, 39(1), 83-128. https://doi.org/10.1016/j.jacceco.2004.04.001

Balsmeier, B., \& Vanhaverbeke, S. (2018). International financial reporting standards and private firms' access to bank loans. European Accounting Review, 27(1), 75-104. https://doi.org/10.1080/09638180.2016.1229207

Barth, M. E., Landsman, W. R., \& Lang, M. H. (2008). International accounting standards and accounting quality. Journal of accounting research, 46(3), 467-498. https://doi.org/10.1111/j.1475-679X.2008.00287.x

Barth, M. E., Landsman, W. R., Lang, M., \& Williams, C. (2012). Are IFRS-based and US GAAP-based accounting amounts comparable? Journal of Accounting and Economics, 54(1), 68-93. https://doi.org/10.1016/j.jacceco.2012.03.001

Beneish, M. D., Miller, B. P., \& Yohn, T. L. (2015). Macroeconomic evidence on the impact of mandatory IFRS adoption on equity and debt markets. Journal of Accounting and Public Policy, 34(1), 1-27. https://doi.org/10.1016/j.jaccpubpol.2014.10.002

Bertrand, J., De Brebisson, H., \& Burietz, A. (2021). Why choosing IFRS? Benefits of voluntary adoption by European private companies. International Review of Law and Economics, 65, 105968. https://doi.org/10.1016/j.irle.2020.105968

Bhat, G., Callen, J. L., \& Segal, D. (2016). Testing the transparency implications of mandatory IFRS adoption: The spread/maturity relation of credit default swaps. Management Science, 62(12), 3472-3493. https://doi.org/10.1287/mnsc.2015.2318

Biddle, G. C., Hilary, G., \& Verdi, R. S. (2009). How does financial reporting quality relate to investment efficiency?. Journal of accounting and economics, 48(2-3), 112-131. https://doi.org/10.1016/j.jacceco.2009.09.001

Bjorvatn, K. (2004). Economic integration and the profitability of cross-border mergers and acquisitions. European Economic Review, 48(6), 1211-1226. https://doi.org/10.1016/j.euroecorev.2004.03.007

Borra, S., \& Di Ciaccio, A. (2004). Il modello di regressione multipla in Borra, S., Di Ciaccio, A. (a cura di), 
Statistica, metodologie per le scienze economiche e sociali. McGraw Hill, (retrieved from www.ateneoonline.it)

Brennan, M. J., \& Cao, H. H. (1997). International portfolio investment flows. The Journal of Finance, 52(5), 1851-1880. https://doi.org/10.1111/j.1540-6261.1997.tb02744.x

Bris, A., \& Cabolis, C. (2008). The value of investor protection: Firm evidence from cross-border mergers. The review of financial studies, 21(2), 605-648. https://doi.org/10.1093/rfs/hhm089

Brüggemann, U., Daske, H., Homburg, C., \& Pope, P. F. (2010). How do individual investors react to global IFRS adoption?. AAA. https://doi.org/10.2139/ssrn.1458944

Bushman, R. M., \& Piotroski, J. D. (2006). Financial reporting incentives for conservative accounting: The influence of legal and political institutions. Journal of accounting and economics, 42(1-2), 107-148. https://doi.org/10.1016/j.jacceco.2005.10.005

Caroli, M. (2012). Gli investimenti diretti esteri in Caroli M. (a cura di), Gestione delle imprese internazionali. McGraw Hill, 65-109.

Cartwright, S., \& Cooper, C. L. (1993). The psychological impact of merger and acquisition on the individual: A study of building society managers. Human relations, 46(3), 327-347. https://doi.org/10.1177/001872679304600302

Cascino, S., \& Gassen, J. (2015). What drives the comparability effect of mandatory IFRS adoption? Review of Accounting Studies, 20(1), 242-282. https://doi.org/10.1007/s11142-014-9296-5

Castillo Merino, D., Menéndez-Plans, C., \& Orgaz-Guerrero, N. (2014). Mandatory IFRS adoption and the cost of equity capital: Evidence from Spanish firms. Intangible Capital, 10(3), 562-583. https://doi.org/10.3926/ic.491

Chan, K., Covrig, V., \& Ng, L. (2009). Does home bias affect firm value? Evidence from holdings of mutual funds worldwide. Journal of international economics, 78(2), 230-241. https://doi.org/10.1016/j.jinteco.2009.04.006

Chen, C. J., \& Yu, C. M. J. (2012). Managerial ownership, diversification, and firm performance: Evidence from an emerging market. International Business Review, 21(3), 518-534. https://doi.org/10.1016/j.ibusrev.2011.06.002

Chen, C. J., Ding, Y., \& Xu, B. (2014). Convergence of accounting standards and foreign direct investment. The International Journal of Accounting, 49(1), 53-86. https://doi.org/10.1016/j.intacc.2014.01.007

Chen, F., Hope, O. K., Li, Q., \& Wang, X. (2011). Financial reporting quality and investment efficiency of private firms in emerging markets. The accounting review, 86(4), 1255-1288. https://doi.org/10.2308/accr-10040

Chen, L., Ng, J., \& Tsang, A. (2015). The effect of mandatory IFRS adoption on international cross-listings. The Accounting Review, 90(4), 1395-1435. https://doi.org/10.2308/accr-50982

Cheung, W., Fung, S., \& Tsai, S. C. (2014). Global capital market interdependence and spillover effect of credit risk: evidence from the 2007-2009 global financial crisis. In The Global Financial Crisis (pp. 89-108). Routledge.

Choi, F. D., \& Meek, G. K. (2008). International accounting. Pearson Education.

Chua, W. F., \& Taylor, S. L. (2008). The rise and rise of IFRS: An examination of IFRS diffusion. Journal of accounting and public policy, 27(6), 462-473. https://doi.org/10.1016/j.jaccpubpol.2008.09.004

Chung, C. Y., Kim, H., \& Ryu, D. (2017). Foreign investor trading and information asymmetry: Evidence from a leading emerging market. Applied Economics Letters, 24(8), 540-544. https://doi.org/10.1080/13504851.2016.1208349

Covrig, V. M., Defond, M. L., \& Hung, M. (2007). Home bias, foreign mutual fund holdings, and the voluntary adoption of international accounting standards. Journal of accounting research, 45(1), 41-70. https://doi.org/10.1111/j.1475-679X.2007.00226.x

Das, S. P., \& Sengupta, S. (2001). Asymmetric information, bargaining, and international mergers. Journal of Economics \& Management Strategy, 10(4), 565-590. https://doi.org/10.1162/105864001753356105

Daske, H., Hail, L., Leuz, C., \& Verdi, R. (2008). Mandatory IFRS reporting around the world: Early evidence on the economic consequences. Journal of accounting research, 46(5), 1085-1142. https://doi.org/10.1111/j.1475-679X.2008.00306.x

Daske, H., Hail, L., Leuz, C., \& Verdi, R. (2013). Adopting a label: Heterogeneity in the economic consequences around IAS/IFRS adoptions. Journal of accounting research, 51(3), $495-547$. https://doi.org/10.1111/1475-679X.12005 
Davis-Friday, P. Y., \& Skaife, A. H. (2008). International Financial Reporting and the Likelihood of Being a Target in a M\&A. Unpublished paper, Baruch College and University of Wisconsin-Madison.

de Moura, A. A. F., Altuwaijri, A., \& Gupta, J. (2020). Did mandatory IFRS adoption affect the cost of capital in Latin American countries? Journal of International Accounting, Auditing and Taxation, 38, 100301. https://doi.org/10.1016/j.intaccaudtax.2020.100301

DeFond, M., Hu, X., Hung, M., \& Li, S. (2011). The impact of mandatory IFRS adoption on foreign mutual fund ownership: The role of comparability. Journal of accounting and economics, 51(3), 240-258. https://doi.org/10.1016/j.jacceco.2011.02.001

Di Giovanni, J. (2005). What drives capital flows? The case of cross-border M\&A activity and financial deepening. Journal of international Economics, 65(1), 127-149. https://doi.org/10.1016/j.jinteco.2003.11.007

Diamond, D. W., \& Verrecchia, R. E. (1991). Disclosure, liquidity, and the cost of capital. The journal of Finance, 46(4), 1325-1359. https://doi.org/10.1111/j.1540-6261.1991.tb04620.x

Dikova, D., Sahib, P. R., \& Van Witteloostuijn, A. (2010). Cross-border acquisition abandonment and completion: The effect of institutional differences and organizational learning in the international business service industry, 1981-2001. Journal of International Business Studies, 41(2), 223-245. https://doi.org/10.1057/jibs.2009.10

Drake, M. S., Roulstone, D. T., \& Thornock, J. R. (2012). Investor information demand: Evidence from Google searches around earnings announcements. Journal of Accounting research, 50(4), 1001-1040. https://doi.org/10.1111/j.1475-679X.2012.00443.x

Ebaid, I. E. S. (2016). International accounting standards and accounting quality in code-law countries. Journal of Financial Regulation and Compliance. https://doi.org/10.1108/JFRC-12-2011-0047

European Commission. (2015). GREEN PAPER Building a Capital Markets Union. Retrieved at: https://eur-lex.europa.eu/legal-content/EN/TXT/?uri=celex\%3A52015DC0063

Florou, A., \& Kosi, U. (2015). Does mandatory IFRS adoption facilitate debt financing? Review of Accounting Studies, 20(4), 1407-1456. https://doi.org/10.1007/s11142-015-9325-z

Francis, J. R., Huang, S. X., \& Khurana, I. K. (2016). The role of similar accounting standards in cross-border mergers and acquisitions. Contemporary Accounting Research, 33(3), 1298-1330. https://doi.org/10.1111/1911-3846.12176

Frost, C. A., Gordon, E. A., \& Hayes, A. F. (2006). Stock exchange disclosure and market development: an analysis of 50 international exchanges. Journal of accounting research, 44(3), 437-483. https://doi.org/10.1111/j.1475-679X.2006.00208.x

Gehrig, T. (1993). An information based explanation of the domestic bias in international equity investment. The Scandinavian Journal of Economics, 97-109. https://doi.org/10.2307/3440137

Graham, J. R., Harvey, C. R., \& Huang, H. (2009). Investor competence, trading frequency, and home bias. Management Science, 55(7), 1094-1106. https://doi.org/10.1287/mnsc.1090.1009

Gray, S. J. (1988). Towards a theory of cultural influence on the development of accounting systems internationally. Abacus, 24(1), 1-15. https://doi.org/10.1111/j.1467-6281.1988.tb00200.x

Hong, H. A., Hung, M., \& Lobo, G. J. (2014). The impact of mandatory IFRS adoption on IPOs in global capital markets. The Accounting Review, 89(4), 1365-1397. https://doi.org/10.2308/accr-50720

Horton, J., Serafeim, G., \& Serafeim, I. (2013). Does mandatory IFRS adoption improve the information $\begin{array}{llll}\text { environment? } \quad \text { Contemporary } & \text { accounting }\end{array}$ https://doi.org/10.1111/j.1911-3846.2012.01159.x

Hossain, M. S. (2021). Merger \& Acquisitions (M\&As) as an important strategic vehicle in business: Thematic areas, research avenues \& possible suggestions. Journal of Economics and Business, 106004. https://doi.org/10.1016/j.jeconbus.2021.106004

IFRS Foundation. (2021a). Why Global Accounting Standards? Retrieved at: https://www.ifrs.org/use-around-the-world/why-global-accounting-standards/

IFRS Foundation. (2021b). How widespread is the adoption of IFRS around the world? Retrieved at: https://www.ifrs.com/ifrs_faqs.html\#q3 
Istiningrum, A. A. (2020). Corporate Governance, IFRS Disclosure, and Stock Liquidity in Indonesian Mining Companies. In 4th International Conference on Management, Economics and Business (ICMEB 2019) (pp. 271-278). Atlantis Press. https://doi.org/10.2991/aebmr.k.200205.047

Jaggi, B., \& Low, P. Y. (2000). Impact of culture, market forces, and legal system on financial disclosures. The international journal of accounting, 35(4), 495-519. https://doi.org/10.1016/S0020-7063(00)00076-5

Jiang, L., \& Kim, J. B. (2004). Foreign equity ownership and information asymmetry: Evidence from Japan. Journal of International Financial Management \& Accounting, $\quad 15(3), \quad 185-211$. https://doi.org/10.1111/j.1467-646X.2004.00107.x

Kainth, A., \& Wahlstrøm, R. R. (2021). Do IFRS Promote Transparency? Evidence from the Bankruptcy Prediction of Privately Held Swedish and Norwegian Companies. Journal of Risk and Financial Management, 14(3), 123. https://doi.org/10.3390/jrfm14030123

Karolyi, G. A. (2006). The world of cross-listings and cross-listings of the world: Challenging conventional wisdom. Review of Finance, 10(1), 99-152. https://doi.org/10.1007/s10679-006-6980-8

Kashiwazaki, R., Sato, S., \& Takeda, F. (2019). Does IFRS adoption accelerate M\&A? The consequences of different goodwill accounting in Japan. International Advances in Economic Research, 25(4), 399-415. https://doi.org/10.1007/s11294-019-09757-0

Key, K. G., \& Kim, J. Y. (2020). IFRS and accounting quality: Additional evidence from Korea. Journal of International Accounting, Auditing and Taxation, 100306. https://doi.org/10.1016/j.intaccaudtax.2020.100306

Kumar, V., \& Sharma, P. (2019). Motives of M\&A and Deal Synergies. In An Insight into Mergers and Acquisitions (pp. 31-43). Palgrave Macmillan, Singapore. https://doi.org/10.1007/978-981-13-5829-6_2

Leuz, C. (2006). Cross listing, bonding and firms' reporting incentives: A discussion of Lang, Raedy and Wilson (2006). Journal of Accounting and Economics, 42(1-2), 285-299. https://doi.org/10.1016/j.jacceco.2006.04.003

Leuz, C., \& Verrecchia, R. E. (2000). The economic consequences of increased disclosure. Journal of accounting research, 91-124. https://doi.org/10.2307/2672910

Leuz, C., Lins, K. V., \& Warnock, F. E. (2009). Do foreigners invest less in poorly governed firms? The Review of Financial Studies, 22(8), 3245-3285. https://doi.org/10.1093/rfs/hhn089

Li, S. (2010). Does mandatory adoption of International Financial Reporting Standards in the European Union reduce the cost of equity capital? The accounting review, 85(2), 607-636. https://doi.org/10.2308/accr.2010.85.2.607

Louis, H., \& Urcan, O. (2014). The effect of IFRS on cross-border acquisitions. Available at https://papers.ssrn.com/sol3/papers.cfm?abstract_id=2164995

Luthan, E., \& Satria, I. (2016). The Effect of Good Corporate Governance Mechanism to Earnings Management Before and After IFRS Convergence. Procedia-Social and Behavioral Sciences, $219,465-471$. https://doi.org/10.1016/j.sbspro.2016.05.021

Marcellina, B., \& Angela, A. (2018). Information Asymmetry in the Post-IFRS Adoption Period: Evidence from Developing Countries. Acc. Fin. Review, 3(4), 114-123. https://doi.org/10.35609/afr.2018.3.4(3)

Moschieri, C., \& Campa, J. M. (2014). New trends in mergers and acquisitions: Idiosyncrasies of the European market. Journal of Business Research, 67(7), 1478-1485. https://doi.org/10.1016/j.jbusres.2013.07.018

Nejad, M. Y., Ahmad, A., Rahim, R. A., \& Salleh, F. M. (2020). Does IFRS Drive Information Asymmetry Reduction? Evidence from Asean-6 Countries. Asian Journal of Accounting and Governance, 14. https://doi.org/10.17576/AJAG-2020-14-08

Nobes, C., Parker, R. B., \& Parker, R. H. (2008). Comparative international accounting. Pearson Education.

OECD. Stat (2021). Retrieved at: https://stats.oecd.org/

Ozkaya, H. (2018). Effect of mandatory IFRS adoption on cost of debt in Turkey. Business and Economics Research Journal, 9(3), 579-588. https://doi.org/10.20409/berj.2018.124

Piccolo, D. (2010). Il modello di regressione lineare in Piccolo D. (a cura di), Statistica, il Mulino, 873-900.

Piotroski, J. D., \& Srinivasan, S. (2008). Regulation and bonding: The Sarbanes-Oxley act and the flow of 
international listings. Journal of Accounting Research, 46(2), 383-425. https://doi.org/10.1111/j.1475-679X.2008.00279.x

Portes, R., \& Rey, H. (2005). The determinants of cross-border equity flows. Journal of international Economics, 65(2), 269-296. https://doi.org/10.1016/j.jinteco.2004.05.002

Pwc. (2017). IFRS adoption by country, 2017. Retrieved at: https://www.pwc.ru/ru/ifrs/ifrs-17-hub-int/pwc-ifrs-by-country-2016.pdf

Quaglia, L., Howarth, D., \& Liebe, M. (2016). The political economy of European capital markets union. J. Common Mkt. Stud., 54, 185. https://doi.org/10.1111/jcms.12429

Radebaugh, L. H., Gray, S. J., \& Black, E. L. (2006). International accounting and multinational enterprises. John Wiley \& Sons.

Rahmani, T., \& Motamedi, S. (2018). The impact of foreign direct investment on capital formation, productivity and economic growth in developing countries. Quarterly Journal of Economic Growth and Development Research, $8(30), 117-132$.

Ramanna, K., \& Sletten, E. (2014). Network effects in countries' adoption of IFRS. The Accounting Review, 89(4), 1517-1543. https://doi.org/10.2308/accr-50717

Rossi, S., \& Volpin, P. F. (2004). Cross-country determinants of mergers and acquisitions. Journal of Financial Economics, 74(2), 277-304. https://doi.org/10.1016/j.jfineco.2003.10.001

Roychowdhury, S., Shroff, N., \& Verdi, R. S. (2019). The effects of financial reporting and disclosure on corporate investment: A review. Journal of Accounting and Economics, 68(2-3), 101246. https://doi.org/10.1016/j.jacceco.2019.101246

Saxena, S. (2012). Mergers and Acquisitions as a Strategic Tool to Gain Competitive Advantage by Exploiting Synergies: A Study of Merging \& Non Merging Firms in Indian Aluminium Industry. This paper was published in edited volume titled Innovation and Adaptability: Twin Engines of Sustained Growth, by Bhakar SS and Pandey VK, Excel Books, New Delhi, 48-61. https://doi.org/10.2139/ssrn.2086114

Seay, S. S. (2014). The economic impact of IFRS-a financial analysis perspective. Academy of Accounting and Financial Studies Journal, 18(2), $119 . \quad$ Retrieved at: https://www.proquest.com/openview/d32e067459c530dc9111dd878a612ace/1?pq-origsite=gscholar\&cbl=2941 4

Shin, H., \& Oh, H. (2017). Mandatory Adoption Of IFRS And Earnings Transparency In Korea. Journal of Applied Business Research (JABR), 33(6), 1129-1138. https://doi.org/10.19030/jabr.v33i6.10050

Soeters, J., \& Schreuder, H. (1988). The interaction between national and organizational cultures in accounting firms. Accounting, Organizations and Society, 13(1), 75-85. https://doi.org/10.1016/0361-3682(88)90026-8

Starks, L. T., \& Wei, K. D. (2013). Cross-border mergers and differences in corporate governance. International Review of Finance, 13(3), 265-297. https://doi.org/10.1111/irfi.12008

Sudarsanam, S. (2003). Creating value from mergers and acquisitions: The challenges: An integrated and international perspective. Pearson Education.

Tan, H., Wang, S., \& Welker, M. (2011). Analyst following and forecast accuracy after mandated IFRS adoptions. Journal of accounting research, 49(5), 1307-1357. https://doi.org/10.1111/j.1475-679X.2011.00422.x

Tranmer, M., \& Elliot, M. (2008). Multiple linear regression. The Cathie Marsh Centre for Census and Survey Research (CCSR), 5(5), $1-5 . \quad$ Retrieved at: http://hummedia.manchester.ac.uk/institutes/cmist/archive-publications/working-papers/2020/multiple-linear-re gression.pdf

Turki, H., Wali, S., \& Boujelbene, Y. (2020). IFRS adoption and cost of capital: moderating effects of growth opportunities and informational environment. International Journal of Accounting and Finance, 10(2-3), 87-110. https://doi.org/10.1504/IJAF.2020.114938

Uyanık, G. K., \& Güler, N. (2013). A study on multiple linear regression analysis. Procedia-Social and Behavioral Sciences, 106, 234-240. https://doi.org/10.1016/j.sbspro.2013.12.027

Van Nieuwerburgh, S., \& Veldkamp, L. (2009). Information immobility and the home bias puzzle. The Journal of Finance, 64(3), 1187-1215. https://doi.org/10.1111/j.1540-6261.2009.01462.x 
Vo, X. V. (2020). Foreign investors and stock price crash risk: Evidence from Vietnam. International Review of Finance, 20(4), 993-1004. https://doi.org/10.1111/irfi.12248

World Bank. (2021). World Bank Development Indicators. Retrivable at the following link: https://databank.worldbank.org/reports.aspx?source=2\&series=BX.KLT.DINV.CD.WD\&country=\#

Wu, C. H., \& Chiang, H. E. (2019). Impact of diversified mergers and acquisitions on corporate risk. Journal of Economics, 15(1), 93-115.

Yu, G., \& Wahid, A. S. (2014). Accounting standards and international portfolio holdings. The Accounting Review, 89(5), 1895-1930. https://doi.org/10.2308/accr-50801

Zhu, W. (2014). The evolving economic role of accounting standards: Evidence from bilateral cross-border M\&A flows. Frontiers of Business Research in China, 8(4), 435-479. https://doi.org/10.3868/s070-003-014-0020-1

\section{Notes}

Note 1. The following countries are considered in the sample: Australia, Austria, Belgium, Canada, Chile, Czech Republic, Denmark, Estonia, Finland, France, Germany, Greece, Hungary, Island, Ireland, Israel, Italy, Japan, Luxembourg, Mexico, Netherlands, Norway, New Zealand, Poland, Portugal, Slovenia, Slovakia, Spain, South Korea, Sweden, Switzerland, Turkey, the United Kingdom, and the United States.

Note 2 . We specify that the variable IFRS ${ }^{\text {Investor }}$ is included in this analysis for completeness, but the variables useful to verify the hypotheses are IFRS ${ }^{\text {Investee }}$ and IFRS ${ }^{\text {Both }}$. 


\section{Appendix A}

Table 11. Analysis 1 (IFRS - FDI) - Correlation analysis (complete)

\begin{tabular}{|c|c|c|c|c|c|c|c|c|c|c|c|c|}
\hline & FDIij & IFRSBoth & IFRS Investor & IFRSInvestee & $\begin{array}{c}\text { GDPGrowth } \\
\text { Investee }\end{array}$ & $\begin{array}{c}\text { InflationRat } \\
\text { eInvestee }\end{array}$ & ImportsInvestee & ExportsInvestee & $\begin{array}{c}\text { GDPPerCapitaGr } \\
\text { owthInvestee }\end{array}$ & $\begin{array}{c}\text { FDINetInflows } \\
\text { Investee }\end{array}$ & $\begin{array}{l}\text { FDIInveste } \\
\text { e/FDIWorld }\end{array}$ & $\begin{array}{c}\text { CorporateIncome } \\
\text { TaxRate }\end{array}$ \\
\hline FDIij & 1 & & & & & & & & & & & \\
\hline IFRSBoth & 0.009933882 & 1 & & & & & & & & & & \\
\hline IFRS Investor & 0.026158807 & 0.727692091 & 1 & & & & & & & & & \\
\hline IFRSInvestee & 0.028070492 & 0.777096968 & 0.408020358 & 1 & & & & & & & & \\
\hline GDPGrowthInvestee & -0.042961597 & -0.144283385 & -0.106609006 & -0.180249459 & 1 & & & & & & & \\
\hline InflationRateInvestee & -0.053140623 & 0.007643274 & -0.005178011 & 0.007162289 & 0.2485839 & 1 & & & & & & \\
\hline ImportsInvestee & 0.206494977 & -0.092119702 & 0.079312992 & -0.1180258 & -0.096578 & -0.1372195 & 1 & & & & & \\
\hline ExportsInvestee & 0.202138716 & -0.059575453 & 0.088715607 & -0.076051817 & -0.11776 & -0.1868868 & 0.970785501 & 1 & & & & \\
\hline \multicolumn{13}{|l|}{ GDPPerCapitaGrowthInves } \\
\hline tee & -0.054040391 & -0.114952739 & -0.110235246 & -0.144878336 & 0.9788457 & 0.22174769 & -0.082652252 & -0.092334153 & 1 & & & \\
\hline FDINetInflowsInvestee & 0.301938076 & 0.009738217 & 0.077035366 & 0.022979084 & -0.013874 & -0.0731723 & 0.586222782 & 0.553274482 & -0.019827438 & 1 & & \\
\hline FDIInvestee/FDIWorld & 0.276794188 & -0.071075415 & -0.032692001 & -0.081958505 & -0.036849 & -0.1181514 & 0.624065687 & 0.578153394 & -0.0440984 & 0.909698786 & 1 & \\
\hline CorporateIncomeTaxRate & 0.056636612 & -0.055092136 & -0.133223174 & -0.061418584 & -0.032075 & -0.06784 & 0.314284724 & 0.260020738 & -0.043226491 & 0.231671286 & 0.2983203 & 1 \\
\hline
\end{tabular}


